\title{
Phenolic profile and antioxidant activity from wild and in vitro cultivated Rhynchostele rossii (Orchidaceae)
}

\section{Perfil de compuestos fenólicos y actividad antioxidante de Rhynchostele rossii (Orchidaceae) silvestre y cultivada in}

\section{Acta Botanica} Mexicana

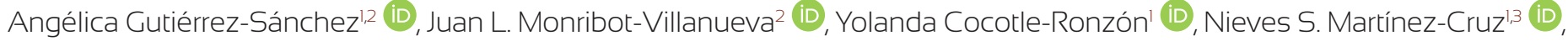 \\ José A. Guerrero-Analco 2,3 (iD)
}

\begin{abstract}
:
Background and Aims: Rhynchostele rossii is an orchid native to Mexico known as gallinitas (little chickens) that is threatened due to overexploitation for ornamental purposes, as a consequence of which it is necessary to realize efforts for its conservation. To date there are no reports of phytochemical studies of this orchid, although it is well known that species of the Orchidaceae family are a good source of bioactive and nutraceutical compounds (e. g. vanillin). Therefore, the main objective of this research was to establish a $R$. rossii in vitro germination protocol for propagation and determination of phenolic compounds that contribute to its phytochemical knowledge.

Methods: A specimen of a wild plant and some seedlings obtained by in vitro culture were dried, milled and their components extracted with MeOH; anti-free radical activity (DPPH), total phenols and flavonoids were determined by spectrophotometric methods, and individual phenolic compounds were identified and quantified by liquid chromatography coupled to mass spectrometry (LC-MS).

Key results: The root of the wild plant showed the highest content of total phenols and flavonoids with $121.60 \mathrm{mg} \mathrm{GAE} \mathrm{g}^{-1}$ and $108.73 \mathrm{mg} \mathrm{CE} \mathrm{g}^{-1}$, respectively, and the best anti-free radical activity with an $\mathrm{IC}_{50} 53.63 \mathrm{\mu g} \mathrm{ml}^{-1}$. Extracts from seedlings obtained by in vitro culture also produced phenolic compounds, showing a total phenolic and flavonoid content of $37.35 \mathrm{mg} \mathrm{GAE} \mathrm{g}^{-1}$ and $0.16 \mathrm{mg} \mathrm{CE} \mathrm{g}^{-1}$, respectively. One coumarin (scopoletin), three cinnamic acids (4-coumaric acid, ferulic acid and trans-cinnamic acid), three benzoic acids (vanillic acid, vanillin and 4-hydroxybenzoic acid) and three flavonoids (quercetin-3-D-galactoside, quercetin-3-glucoside and kaempferide) were identified and quantified by LC-MS.

Conclusions: This study demonstrates that $R$. rossii is a potential source of antioxidant metabolites that can be obtained by in vitro culture, without harming the wild specimens.
\end{abstract}

Key words: biotechnology, orchid in vitro propagation, secondary metabolites.

\section{Resumen:}

Antecedentes y Objetivos: Rhynchostele rossii es una orquídea nativa de México conocida como gallinitas, que está amenazada debido a su sobreexplotación con fines ornamentales, lo que hace necesario realizar esfuerzos para su conservación. A la fecha, no hay estudios fitoquímicos de esta orquídea, aunque se sabe que las especies de la familia Orchidaceae son una buena fuente de compuestos bioactivos y nutracéuticos (p. ej. vainillina). Por lo anterior, el objetivo principal de esta investigación fue establecer el protocolo de geminación in vitro de $R$. rossii para la propagación de la especie y la determinación de compuestos fenólicos que contribuyan al conocimiento fitoquímico de esta planta.

Métodos: Un ejemplar silvestre y algunas plántulas obtenidas por cultivo in vitro se secaron, molieron y extrajeron con $\mathrm{MeOH}$; se determinó la actividad de anti-radicales libres (DPPH), fenoles y flavonoides totales por métodos espectrofotométricos y algunos fenoles se identificaron y cuantificaron por cromatografía de líquidos acoplada a espectrometría de masas (LC-MS).

Resultados clave: La raíz de la planta silvestre mostró el mayor contenido de fenoles y flavonoides totales con $121.60 \mathrm{mg} \mathrm{GAE} \mathrm{g}^{-1}$, y 108.73 mg CE g ${ }^{-1}$, respectivamente, y la mejor actividad anti-radicales libres con una $\mathrm{IC}_{50}$ de $53.63 \mathrm{\mu g} \mathrm{ml}^{-1}$. Los extractos de las plántulas obtenidas in vitro también produjeron compuestos fenólicos, mostrando un contenido de fenoles y flavonoides totales de $37.35 \mathrm{mg} \mathrm{GAE} \mathrm{g}^{-1}$ y $0.16 \mathrm{mg} \mathrm{CE} \mathrm{g}^{-1}$, respectivamente, mientras que por LC-MS se identificaron y cuantificaron una cumarina (escopoletina), tres ácidos cinámicos (ácido 4-cumárico, ácido ferúlico y ácido trans-cinamico), tres ácidos benzoicos (ácido vainillico, vainillina y acido 4-hidroxibenzoico) y tres flavonoides (quercetina-3-D-galactósido, quercetina-3-glucósido y kaempferide).

Conclusiones: Este estudio muestra que $R$. rossii es una fuente potencial de metabolitos antioxidantes que pueden obtenerse mediante cultivo in vitro, sin perjudicar a los ejemplares silvestres.

Palabras clave: biotecnología, metabolitos secundarios, propagación in vitro de orquídeas.

\footnotetext{
${ }^{1}$ Universidad Veracruzana, Facultad Química Farmacéutica Biológica, Circuito Gonzalo Aguirre Beltrán s/n, Zona Universitaria, 91000 Xalapa, Veracruz, Mexico.

${ }^{2}$ Instituto de Ecología, A. C., Red de Estudios Moleculares Avanzados, Carretera antigua a Coatepec No. 351, Col. El Haya, 91070 Xalapa, Veracruz, Mexico.

${ }^{3}$ Authors for correspondence: joseantonio.guerrero@ inecol.mx; nimartinez@uv.mx
}

Received: January 29, 2020.

Reviewed: April 3, 2020

Accepted by Marie-Stéphanie Samain: May 5, 2020.

Published Online first: May 29, 2020.

Published: Acta Botanica Mexicana 127 (2020).

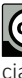

To cite as:

Gutiérrez-Sánchez, A., J. L. Monribot-Villanueva, Y. Cocotle-Ronzón, N. S. Martínez-Cruz and J. A. GuerreroAnalco. 2020. Phenolic profile and antioxidant activity from wild and in vitro cultivated Rhynchostele rossii (Orchidaceae). Acta Botanica Mexicana 127: e1665. DOI: 10.21829/abm127.2020.1665

e-ISSN: 2448-7589 


\section{Introduction}

The Orchidaceae family is constituted by 736 genera and ca. 28,000 species, being one of the largest and diverse plant groups worldwide (Chase et al., 2015; Fay, 2018). There are 1260 species in Mexico, of which 433 grow in the state of Veracruz (Castañeda-Zárate et al., 2012; Baltazar-Bernal et al., 2014). Some of these species have traditionally been used in ethnomedicine for the treatment of illnesses (Cano Asseleih et al., 2015) and consequently, some of them have already been phytochemically studied or biotested for finding a biological potential. Bioactive orchid secondary metabolites include terpenoids, polyphenols and flavonoids, which have shown antioxidant activity and proven application as antibacterial agents (Bhattacharyya et al., 2014; Chand et al., 2016; Bhatnagar et al., 2017).

Rhynchostele rossii (Lindl.) Soto Arenas \& Salazar is an epiphytic orchid native from Mexico that grows in the cloud forest region of the state of Veracruz, where it is given the common name of gallinitas (little chickens). Its distribution extends from Mexico to Guatemala, El Salvador, Honduras and Nicaragua (Menchaca-García and Moreno-Martínez, 2010). Due to its recognized use as ornament, which has resulted in illegal overexploitation, this orchid belongs to the category of threatened according to the Mexican environmental protection norm NOM-059-SEMARNAT-2010 (SEMARNAT, 2010). Plants in this category are considered in danger of disappearing in the short or medium term, if factors that negatively affect their viability continue decreasing the size of populations, such as the looting of specimens for selling, destruction of their habitat and low germination percentage (Rasmussen et al., 2015; Hinsley et al., 2018). Although $R$. rossii is not traditionally used for medicinal purposes, on the basis of the ecological and chemotaxonomic criteria, it is necessary to look for alternatives for their rescue, conservation and rational use as source of bioactive metabolites with applications in sectors such as pharmaceutical, food, cosmetology, among others.

In vitro plant tissue culture is an alternative to satisfy the commercial demand of $R$. rossii and to contribute to the conservation of wild specimens. This technique offers an effective method for the multiplication of threatened plants and to obtain secondary metabolites with biological activities (Pant, 2013; Utami et al., 2017). An example of important biological metabolites for health, food and biotechnological sectors are phenolic compounds. Some beneficial effects of these compounds have been ascribed to their antimicrobial and antioxidant activity, which helps to prevent infectious and degenerative diseases (Pandey and Rizvi, 2009).

Phenols are one of the most abundant groups of molecules, with at least 10,000 different compounds with a diverse range of beneficial bioactivities (Rasouli et al., 2017). In plants, polyphenols protect against UV radiation, pathogens and oxidative stress, among other biotic and abiotic factors (Di Ferdinando et al., 2014). In the human body, polyphenols act as antioxidants, and have diverse biological properties such as antidiabetic, anticancer, anti-inflammatory, neuroprotective, hepatoprotective, antifungal, antibacterial and antiaging (Ganesan and Xu, 2017). In this sense, in vitro culture has enabled the accumulation of phenolic compounds in cells grown under controlled conditions (Bhattacharyya et al., 2014), which makes this technique an alternative not only for the conservation of threatened species, but also for obtaining secondary metabolites without collecting wild plants. The main objectives of this investigation were to establish the protocol of $R$. rossii in vitro germination for its propagation and to determine the phenolic compounds content, as well as its antioxidant activity in wild plants compared to in vitro plants.

\section{Materials and Methods}

\section{Collection of biological material}

The collection of the orchid $R$. rossii was carried out in the municipality of Chiconquiaco, in the state of Veracruz, Mexico. A capsule was collected for in vitro culture, as well as a small plant for phytochemical analysis and a flowering specimen for its taxonomic identification by the staff of the herbarium XAL of the Instituto de Ecología, A.C., where it has been deposited as the voucher Gutiérrez 1 (XAL).

\section{In vitro germination}

For the in vitro germination, a previously reported and standardized protocol with a good percentage of seed germination was used (Ješvnik and Luthar, 2015). For this, the capsule obtained from the wild plant was disinfected by soaking in detergent for $10 \mathrm{~min}$, and immersed in 0.5\% Bravo $500^{\circledR}$ (aqueous solution; Phthalonitrile $0.36 \%$, Syngenta) for 
10 min. Next, it was immersed in $70 \% \mathrm{EtOH}$ (aqueous solution) for 10 seconds and finally placed for 20 min in $20 \%$ of commercial bleach ( $\mathrm{NaClO}$; aqueous solution) with $0.1 \mathrm{ml} \mathrm{I}^{-1}$ of Tween 20. Between each of the steps indicated and at the end of the process, it was rinsed with sterile distilled water.

In a laminar flow hood, a transversal cut was made in the capsule and the seeds were spread on MS medium (Murashige and Skoog, 1962) with $1 \mathrm{~g} \mathrm{l}^{-1}$ of activated charcoal and $30 \mathrm{~g} \mathrm{l}^{-1}$ of sucrose at $\mathrm{pH} 5.8 \pm 0.5$. The seeds were left to germinate initially in the dark at room temperature $\left(20-25^{\circ} \mathrm{C}\right.$ ). After germination ( 90 days), once the seed volume began to increase due to water absorption, these were replanted and incubated at $22 \pm 2{ }^{\circ} \mathrm{C}$ with a $16 \mathrm{~h}$ photoperiod and a 1180 Lux white light lamp (Prendo INO650V-9, Puebla, Mexico). Six months later, $2.25 \mathrm{~g}$ of seedlings were taken for a subsequent extraction of metabolites and the remaining material was kept in in vitro conditions.

\section{Preparation of extracts}

Fresh material of leaves (15 g), pseudobulbs (695 g) and roots $(61 \mathrm{~g})$ from wild plant and in vitro germinated seedlings (2.25 g) were dried in an oven (Labtron Scientific VDO6050D, Hampshire, UK) at $45 \pm 2{ }^{\circ} \mathrm{C}$ for 3 to 4 days. The dried material was ground and placed in Erlenmeyer flasks. $\mathrm{MeOH}$ was added to completely cover the tissues, and these were placed on an orbital shaker (Dragon lab, SK-033-PRO, Beijing, China) at $150 \mathrm{rpm}$ for 24 hours. Finally, the extracts were filtered and concentrated to dryness in a rotary evaporator under reduced pressure (BÜCHI R210, Flawil, Switzerland).

\section{Quantification of total phenols and flavonoids}

For total phenols quantification, the Folin-Ciocalteu method was used as previously reported by Singleton and Rossi (1965) and Bhattacharyya et al. (2014). For this, a calibration curve was made from 0.004 to $0.4 \mathrm{mg} \mathrm{ml}^{-1}$ of gallic acid in $\mathrm{H}_{2} \mathrm{O} / \mathrm{MeOH}$ (1:1). $250 \mu \mathrm{l}$ of each calibration point, plant extracts and blank $\left(\mathrm{H}_{2} \mathrm{O}\right)$ were taken and placed in tubes protected from light. Five hundred $\mu \mathrm{l}$ of Folin-Ciocalteu reagent (Sigma-Aldrich, F9252) (1:10 in $\mathrm{H}_{2} \mathrm{O}$ ) was added to each tube, and allowed to react for $5 \mathrm{~min}$. Then, $500 \mu \mathrm{l}$ of $7 \% \mathrm{Na}_{2} \mathrm{CO}_{3}$ (aqueous solution) was added, homogenized and, after incubation for $90 \mathrm{~min}$ at room temperature in darkness, the absorbance was measured in a UV/Vis spectrophotometer
(Thermo Scientific Genesys 10, Waltham, Massachusetts, USA) at $\lambda=750 \mathrm{~nm}$. Total phenolic content was expressed as mean of three replicates \pm standard deviation in milligrams of gallic acid equivalents per gram of dry weight (mg GAE $\left.\mathrm{g}^{-1} \pm \mathrm{SD}\right)$.

The quantification of flavonoids was performed according to the $\mathrm{AlCl}_{3}$ test (Zhishen et al., 1999; Bhattacharyya et al., 2014). A catechin calibration curve was prepared in $\mathrm{H}_{2} \mathrm{O}-\mathrm{MeOH}(1: 1)$ from 0.004 to $0.4 \mathrm{mg} \mathrm{ml}^{-1}$. From the dilutions of the standard, extract and blank, $150 \mu$ was taken and placed in test tubes protected from light. After this, 40 $\mu \mathrm{l}$ of $5 \% \mathrm{NaNO}_{2}$ (aqueous solution) was added and tubes were incubated for $5 \mathrm{~min}$. Then, $40 \mu \mathrm{l}$ of $10 \% \mathrm{AlCl}_{3}$ (aqueous solution) was added and left one more minute. Finally, 250 $\mu \mathrm{l}$ of $1 \mathrm{M} \mathrm{NaOH}$ (aqueous solution) and $750 \mu \mathrm{l}$ of distilled water were added. This solution was homogenized, and the absorbance was measured at $\lambda=510 \mathrm{~nm}$ in a UV/Vis spectrophotometer (Thermo Scientific Genesys 10, Waltham, Massachusetts, USA). The total flavonoid content in the samples was expressed as the mean of three replicates \pm standard deviation in milligrams of catechin equivalents per gram of dry weight (mg CE g $\left.{ }^{-1} \pm S D\right)$.

\section{DPPH free radical scavenging}

Free-radical scavenging activity was determined by the method of 2,2-diphenyl-1-picrylhydrazine (DPPH; Sigma-Aldrich, D9132) according to Brand-Williams et al. (1995). As a standard, a vitamin C calibration curve from 0 to $20 \mu \mathrm{g} \mathrm{ml}^{-1}$ was performed, and for each extract evaluation a curve from 10 to $100 \mu \mathrm{g} \mathrm{ml}^{-1}$ was prepared. From each dilution (vitamin C or extract), $250 \mu \mathrm{l}$ was added to $750 \mu \mathrm{l}$ of $0.1 \mathrm{mM} \mathrm{DPPH}$ $\mathrm{MeOH}$ solution. The tubes were protected from light and incubated at room temperature for $30 \mathrm{~min}$. Finally, the absorbance was measured with a spectrophotometer at $\lambda=517 \mathrm{~nm}$ in a UV/Vis spectrophotometer (Thermo Scientific Genesys 10, Waltham, Massachusetts, USA). $\mathrm{MeOH}$ was used as a blank and the concentration capable of neutralizing $50 \%$ of the free radicals DPPH $\left(\mathrm{IC}_{50}\right)$ was determined.

\section{Identification of phenolic compounds by LC-MS} The identification and quantification of individual phenolic compounds in the wild and in vitro plants was performed by liquid chromatography (LC) (Agilent Technologies 1290 In- 
finity series, Santa Clara, California, USA) coupled to a triple quadrupole mass spectrometer (MS-QqQ) (Agilent Technologies 6460, Santa Clara, California, USA), following the dynamic multiple reactions monitoring method reported by Juárez-Trujillo et al. (2018). All the solvents used were MS grade and purchased from Sigma-Aldrich. The chromatographic analysis was carried out on a ZORBAX SB-C18 column (1.8 $\mu \mathrm{m}, 2.1 \times 50 \mathrm{~mm}$ ) of Agilent Technologies (Santa Clara, California, USA). The column oven at $40{ }^{\circ} \mathrm{C}$ and the mobile phase consisted of water $(A)$ and acetonitrile $(B)$, both with $0.1 \%$ of formic acid. The gradient conditions were: $0 \mathrm{~min}, 1 \%$ of B; $0.1-40$ min, linear gradient $1-40 \%$ of B; $40.1-42$ min, linear gradient $40-90 \%$ of $B$; $42.1-44 \mathrm{~min}$, isocratic $90 \%$ of $B$; 44.1-46 min, linear gradient $90-1 \%$ of B; 46.1-47 min, isocratic $1 \%$ of $B$. Total run time was $47 \mathrm{~min}$. The flow rate was $0.1 \mathrm{ml} \mathrm{min}^{-1}$. For injection, $20 \mathrm{mg}$ of each sample extract was diluted in $1 \mathrm{ml}$ of $0.1 \%$ formic acid in $\mathrm{MeOH}$ and then filtered with a $0.2 \mu \mathrm{m}$ membrane, with $5 \mu$ as the injection volume. The electrospray ionization source was operated in positive and negative ionization modes. The desolvation temperature was $300^{\circ} \mathrm{C}$, the cone gas $\left(\mathrm{N}_{2}\right)$ flow rate was $51 \mathrm{~min}^{-1}$, the nebulizer pressure was 45 psi, the sheath gas flow was $11 \mathrm{I} \mathrm{min}^{-1}$ and the capillary voltage (positive and negative) was $500 \mathrm{~V}$. The fragmentor voltage was $100 \mathrm{~V}$ and the cell accelerator voltage was $7 \mathrm{~V}$ for all compounds. The phenolic compounds identity was confirmed by coelution with authentic standards analyzed under the same conditions. For quantitation, a calibration curve in a concentration range from 1 to $9 \mu \mathrm{M}$ was prepared for each standard. $r^{2}$ values $\geq 0.97$ were considered for the quantification range. The data were processed with the MassHunter workstation software, version B.06.00 of Agilent Technologies (Santa Clara, California, USA). The results were expressed as mean of three replicates \pm standard deviation of $\mu \mathrm{g} \mathrm{g}^{-1}$ of dry weight.

\section{Results}

\section{In vitro germination}

The successful germination of seeds of $R$. rossii was achieved, starting about two weeks after sowing, when the seeds increased in size due to water absorption and changed from a white to intense green color. The first leaf development was observed 14 weeks (approximately 95-100 days; Fig. 1A) after sowing and finally one year after its maintenance in vitro, the seedlings reached an average height of $5 \mathrm{~cm}$ (Fig. 1B).

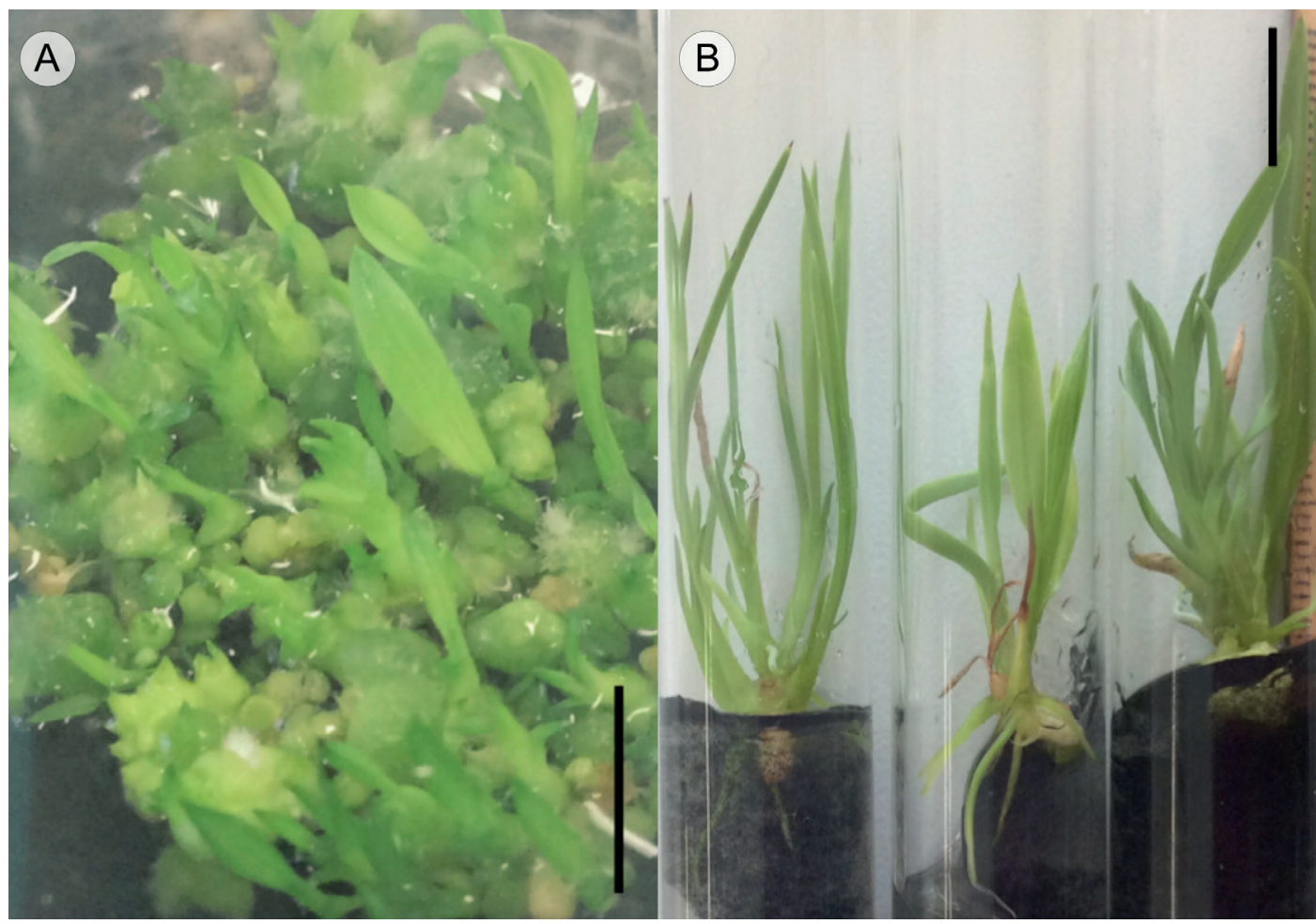

Figure 1: In vitro germination of Rhynchostele rossii (Lindl.) Soto Arenas \& Salazar. A. tissues 195 days after germination (Bar: $1 \mathrm{~cm}$ ); B. R. rossii seedlings after a year of in vitro development (Bar: $1 \mathrm{~cm})$. 
Antioxidant activity, phenolic and flavonoid content

Total phenols and flavonoids were determined in plants of wild origin and in vitro germinated seedlings (Table 1 ). In the wild plants, the highest content of phenols and flavonoids was present in the root with $121.60 \pm 2.99 \mathrm{mg} \mathrm{GAE}$ $\mathrm{g}^{-1}$ and $108.73 \pm 1.13 \mathrm{mg} \mathrm{CE} \mathrm{g}^{-1}$, respectively. Seedlings obtained in vitro presented a total phenolic and flavonoids content of $37.34 \pm 3.45 \mathrm{mg} \mathrm{GAE} \mathrm{g}^{-1}$ and $0.16 \pm 0.08 \mathrm{mg} \mathrm{CE} \mathrm{g}^{-1}$, respectively. These concentrations are lower than those in the roots, but higher than those in the pseudobulbs of the wild plants.

Finally, the highest antioxidant activity was found in the extract of wild plant roots with an $\mathrm{IC}_{50}$ of $53.64 \pm 0.82 \mu \mathrm{g}$ $\mathrm{ml}^{-1}$. This results correlates with the high content of phenols and flavonoids present in this tissue. The second highest antioxidant activity was present in the $\mathrm{MeOH}$ extract of in vitro seedlings with an $\mathrm{IC}_{50}$ of $126.68 \pm 0.98 \mu \mathrm{g} \mathrm{ml}^{-1}$, followed by wild plant pseudobulbs and leaves with the lowest antioxidant activity, since it requires up to $423.11 \pm 1.34 \mathrm{\mu g} \mathrm{ml}^{-1}$ to inhibit $50 \%$ of DPPH free radicals.

Identification and quantification of phenolic compounds

A total of 10 phenolic compounds were identified for the first time in $\mathrm{MeOH}$ extracts of plants of wild origin of $R$. rossii. From the identified compounds, three were cinnamic acids, three flavonoids, three benzoic acids and one coumarin (Table 2). Representative chromatograms of authentic standards and analyzed samples are shown in Fig 2 . The compounds identified are 4-hydroxybenzoic acid (1), vanillic acid (2), vanillin (3), 4-coumaric acid (4), scopoletin (5), ferulic acid (6), quercetin-3-D-galactoside (7), quercetin-3-glucoside (8), trans-cinnamic acid (9) and kaempferide (10) (Fig. 2). In wild plants, five phenolic compounds were shared by pseudobulb, leaf and root tissues (4-coumaric, ferulic, trans-cinnamic, vanillic and 4-hydroxybenzoic acids). One flavonoid was only found in the pseudobulb (kaempferide), while the quercetin derivatives did only occur in leaf tissues. The wild and in vitro plants shared seven phenolic compounds (4-coumaric, ferulic, vanillic, 4-hydroxybenzoic acids, vanillin, quercetin-3-D-galactoside and kaempferide). Interestingly, scopoletin, trans-cinnamic acid and quercetin-3-glucoside were only found in wild tissues, while no phenolic compounds were detected exclusively in in vitro plants (Table 2 ).

The major cinnamic acids found in wild plants were ferulic acid $\left(99.37 \pm 3.58 \mu \mathrm{g} \mathrm{g}^{-1}\right)$ and 4-coumaric acid $\left(20.68 \pm 0.27 \mathrm{~g} \mathrm{~g} \mathrm{~g}^{-1}\right)$ in roots, while trans-cinnamic acid presented the maximum concentration in leaves $(10.11 \pm 0.29$ $\left.\mu \mathrm{g} \mathrm{g}^{-1}\right)$. In contrast, in vitro plants showed higher concentration of 4-coumaric acid $\left(34.37 \pm 1.86 \mu \mathrm{g} \mathrm{g}^{-1}\right)$ and ferulic acid $\left(20.66 \pm 1.97 \mu \mathrm{g} \mathrm{g}^{-1}\right)$, while trans-cinnamic acid was not found. Scopoletin is a coumarin that was only observed in roots of wild plants $\left(0.65 \pm 0.07 \mu \mathrm{g} \mathrm{g}^{-1}\right)$. Regarding flavonoids in wild plants, quercetin-3-D-galactoside and quercetin-3-glucoside were detected in leaf tissues (22.94 \pm 3.30 and $35.12 \pm 2.58 \mu^{-1}$ g , respectively), while kaempferide did only occur in the pseudobulbs $\left(2.62 \pm 0.00 \mu \mathrm{g} \mathrm{g}^{-1}\right)$. In contrast to what was observed in wild plants, only quercetin-3-D-ga-

Table 1: Phenols and flavonoids total content and free antiradical activity in MeOH extracts of wild Rhynchostele rossii (Lindl.) Soto Arenas \& Salazar tissues and in vitro seedlings. Results are expressed as the mean $\pm S D(n=3)$. Ascorbic acid with an experimental IC ${ }_{50}$ of $14.55 \pm 0.16 \mu g \mathrm{ml}^{-1}$, similar to Espinosa-Leal et al. (2015) who report an IC ${ }_{50}$ of $14.13 \mu \mathrm{g} \mathrm{ml}^{-1}$. Different letters indicate significant differences between samples ( $\left.\mathrm{p}<0.05\right)$. GAE: Gallic acid equivalents; CE: Catechin equivalents; IC: Inhibitory concentration.

\begin{tabular}{|c|c|c|c|c|}
\hline \multirow{2}{*}{ Properties } & \multicolumn{4}{|c|}{ Tissue } \\
\hline & Pseudobulb & Leaf & Root & In vitro \\
\hline Total phenols (mg GAE g ${ }^{-1}$ ) & $35.18 \pm 1.61^{\mathrm{a}}$ & $45.36 \pm 2.90^{b, c}$ & $121.60 \pm 2.99^{c}$ & $37.34 \pm 3.45^{a, b}$ \\
\hline Total flavonoids (mg CE g-1) & $13.58 \pm 1.07^{a, c}$ & $25.20 \pm 2.29^{a, b}$ & $108.73 \pm 1.13^{b}$ & $0.16 \pm 0.08^{c}$ \\
\hline $\begin{array}{l}\text { Antiradical activity } \\
\mathrm{IC}_{50}\left(\mu \mathrm{g} \mathrm{m}^{-1}\right)\end{array}$ & $190.40 \pm 4.97^{\mathrm{a}, \mathrm{b}}$ & $423.11 \pm 1.34^{a}$ & $53.64 \pm 0.82^{c}$ & $126.68 \pm 0.98^{b, c}$ \\
\hline
\end{tabular}


Table 2: Phenolic compounds identified in $\mathrm{MeOH}$ extracts from Rhynchostele rossii (Lindl.) Soto Arenas \& Salazar. Concentrations are expressed in $\mu \mathrm{g}$ $\mathrm{g}^{-1}$ of dry weight. Results are expressed as the mean $\pm \mathrm{SD}(\mathrm{n}=3)$. RT: Retention time. ND=Not detected. NQ: Detected but not quantified due to is low value. *Concentration below the limit of quantification.

\begin{tabular}{|c|c|c|c|c|c|c|c|c|}
\hline \multirow{2}{*}{$\begin{array}{l}\text { Chemical } \\
\text { group }\end{array}$} & \multirow{2}{*}{ Metabolites } & \multirow{2}{*}{$\begin{array}{l}\text { Precursor } \\
\text { ion }(\mathrm{m} / \mathrm{z})\end{array}$} & \multirow{2}{*}{$\begin{array}{l}\text { Product } \\
\text { ion }(\mathrm{m} / \mathrm{z})\end{array}$} & \multirow{2}{*}{ RT (min) } & \multicolumn{4}{|c|}{ Tissue } \\
\hline & & & & & Pseudobulb & Leaf & Root & In vitro \\
\hline \multirow[t]{2}{*}{ Coumarins } & Scopoletin & 355.10 & 193.00 & 18.6 & ND & ND & $0.65 \pm 0.07$ & ND \\
\hline & 4-Coumaric acid & 163.05 & 119.00 & 16.4 & $2.31 \pm 0.01$ & $3.44 \pm 0.02$ & $20.68 \pm 0.27$ & $34.37 \pm 1.86$ \\
\hline \multirow[t]{3}{*}{ Cinnamic acids } & Ferulic acid & 193.10 & 133.90 & 18.8 & $1.63 \pm 0.01$ & $8.90 \pm 0.28$ & $99.37 \pm 3.58$ & $20.66 \pm 1.97$ \\
\hline & trans-Cinnamic acid & 147.01 & 103.05 & 28.7 & $5.93 \pm 0.08$ & $10.11 \pm 0.29$ & $2.95 \pm 0.04$ & ND \\
\hline & Vanillic acid & 169.04 & 151.04 & 12.0 & $5.05 \pm 0.14$ & $57.51 \pm 0.82$ & $7.46 \pm 0.09$ & $26.04 \pm 3.92$ \\
\hline \multirow[t]{3}{*}{ Benzoic acids } & Vanillin & 153.00 & 93.00 & 15.3 & NQ & NQ & $4.77 \pm 0.02$ & $16.89 \pm 0.04$ \\
\hline & 4-Hydroxybenzoic acid & 137.02 & 93.03 & 9.4 & $2.19 \pm 0.01$ & $16.96 \pm 1.18$ & $1.00 \pm 0.00$ & $9.46 \pm 0.64$ \\
\hline & $\begin{array}{l}\text { Quercetin-3-D- } \\
\text { galactoside }\end{array}$ & 465.10 & 303.04 & 20.6 & NQ & $22.94 \pm 3.30$ & ND & $11.70 \pm 0.8^{*}$ \\
\hline \multirow[t]{2}{*}{ Flavonoids } & Quercetin-3-glucoside & 465.20 & 303.40 & 20.9 & NQ & $35.12 \pm 2.58$ & ND & ND \\
\hline & Kaempferide & 301.07 & 258.05 & 43.3 & $2.62 \pm 0.00$ & $N Q$ & ND & $2.10 \pm 0.08 *$ \\
\hline
\end{tabular}

lactoside $\left(11.70 \pm 0.80 \mu \mathrm{g} \mathrm{g}^{-1}\right)$ and kaempferide $(2.10 \pm 0.08$ $\mu \mathrm{g} \mathrm{g}^{-1}$ ) were detected in in vitro plants. Moreover, some benzoic acids were found in wild and in vitro plants. Vanillic $\left(57.51 \pm 0.82 \mathrm{\mu g} \mathrm{g}^{-1}\right)$ and 4-hydroxybenzoic $(16.96 \pm 1.18$ $\left.\mu \mathrm{g} \mathrm{g}^{-1}\right)$ acids did mainly occur in leaf tissues, while vanillin $\left(4.77 \pm 0.02 \mu \mathrm{g} \mathrm{g}^{-1}\right)$ was found only in roots of wild plants. In in vitro plants, vanillic acid $\left(26.04 \pm 3.92 \mu \mathrm{g} \mathrm{g}^{-1}\right)$, vanillin $\left(16.89 \pm 0.04 \mathrm{\mu g} \mathrm{g}^{-1}\right)$ and 4-hydroxybenzoic acid $(9.46 \pm 0.64$ $\mu \mathrm{g} \mathrm{g}^{-1}$ ) were detected.

\section{Discussion}

\section{In vitro germination}

To date, only two studies have been conducted on species of Rhynchostele Rchb. f., first to analyze its macronutrients content (Jiménez-Peña et al., 2018) and the second focused on the isolation and study of associated mycorrhizal fungi (Cruz-Higareda et al., 2015). However, none of them has focused on their in vitro culture, although they are highly valuable resources for ornamental purposes (CastiIlo-Pérez et al., 2019). In this study, the asymbiotic in vitro germination of the wild orchid $R$. rossii was achieved. The disinfection method applied to the capsule was effective to obtain an aseptic in vitro culture. Only full-strength MS medium was tested with good results for germination and development of tissues; nevertheless, for other orchids, half or quarter strength MS medium is commonly used with optimal results (Chen et al., 2015). Hence, it would be appropriate to continue testing different media and concentrations to evaluate their effect on growth and optimize production. Seed germination started about two weeks after sowing, like Paul et al. (2012) reported for Dendrobium hookerianum Lindl., when the seeds increased in size due to water absorption and changed from a white to intense green color. 


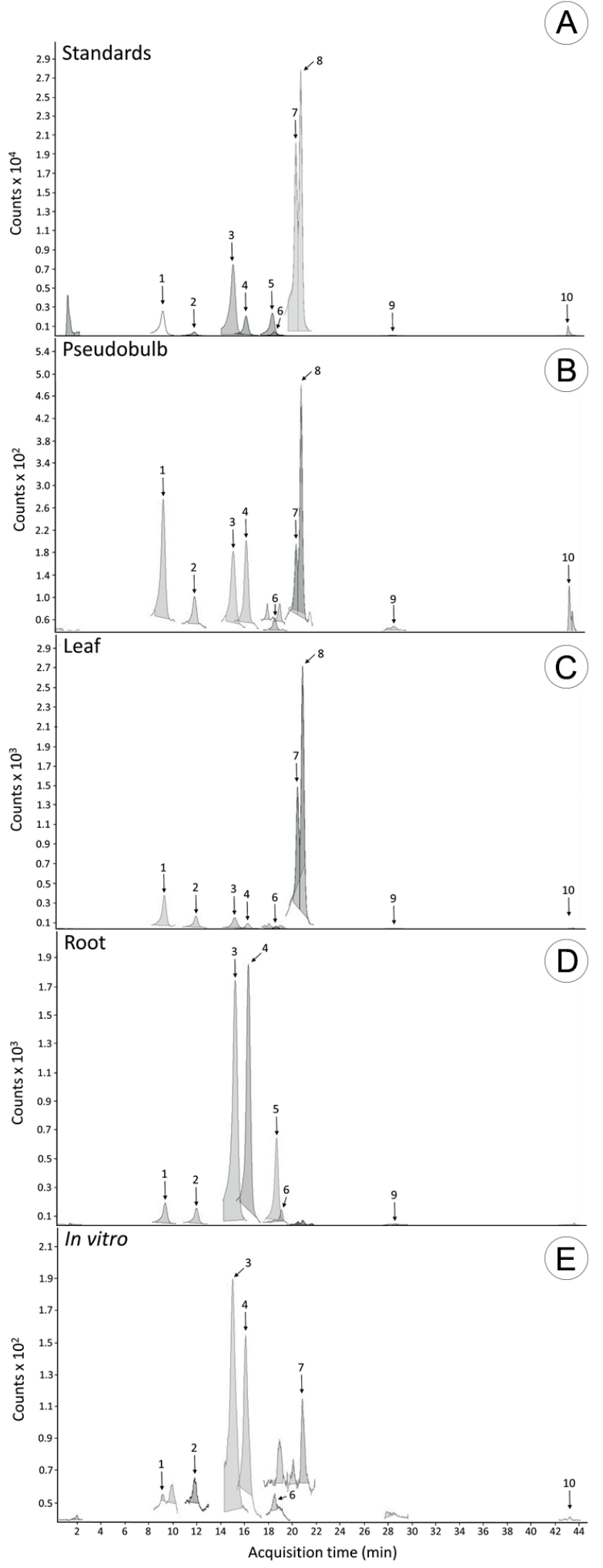

Figure 2: Representative chromatograms of: A. standards; B. pseudobulb; C. leaf; D. root; E. in vitro plants of Rhynchostele rossii (Lindl.) Soto Arenas \& Salazar. The compounds identified are: 4-hydroxybenzoic acid (1), vanillic acid (2), vanillin (3), 4-coumaric acid (4), scopoletin (5), ferulic acid (6), quercetin-3-D-galactoside (7), quercetin-3-glucoside (8), transcinnamic acid (9) and kaempferide (10).
In vitro culture of $R$. rossii is a viable alternative for its propagation, and this biotechnological strategy can be applied for commercial aims, but most importantly for rescue, conservation and even long-term reintroduction purposes (Khamchatra et al., 2016). This technique can also be applied for the phytochemical study of this species, without extracting or damaging wild plants and to obtain metabolites of interest for food or pharmaceutical industries in a more efficient and controlled manner (Giri et al., 2012). Phenols are one of the main natural compounds that already have been reported as compounds in orchids, in different tissues such as leaves, roots or stems (Minh et al., 2017), and it is also known that they are naturally produced under in vitro conditions (Chugh et al., 2009).

\section{Antioxidant activity, phenolic and flavonoid con- tent}

Phenolic compounds produced by plants can act as antioxidant, UV protection, signal and defence compounds (Petruk et al., 2018). In human health, they are very important for their anti-inflammatory, antioxidant or antiproliferative activity (Lin et al., 2016). For example, flavonoids are a kind of polyphenol metabolites with various bioactive effects such as antiviral, cardioprotective or antidiabetic (Wang et al., 2018).

Roots are the tissue where the largest accumulation of phenolic compounds occurs, which could be due to the structure called velamen that covers the roots and that is responsible for the absorption of water and nutrients from the medium (Zotz and Winkler, 2013). It is also important to mention that in nature, this type of orchids establish symbiotic relationships with mycorrhizal fungi (Zhang et al., 2018), so this is an important biotic factor to consider in the biosynthesis and storage of secondary metabolites in $R$. rossii roots.

On the other hand, the phenolic content of an in vitro plant is low when comparing with leaf and root tissues from the wild plant and with in vitro cultivated Dendrobium nobile Lindl., whose $\mathrm{MeOH}$ extract presented a total phenolic content of $41.39 \pm 0.1 \mathrm{mg} \mathrm{GAE} \mathrm{g}^{-1}$ dry weight (Bhattacharyya et al., 2014). Hence, it will be necessary to evaluate other culture conditions such as $\mathrm{pH}$, light, carbon source or minerals, to fine-tune and evaluate how these factors influence 
the production and accumulation of phenolic compounds (Ramakrishna and Ravishankar, 2011; Murthy et al., 2014). Even the use of plant growth regulators for generation of callus and cell suspension or in vitro culture of roots can be tested (Tokuhara and Mii, 2001; Hussain et al., 2012).

Identification and quantification of phenolic compounds

All phenolic compounds have a building block that is a carbon skeleton $\mathrm{C}_{6}-\mathrm{C}_{3}$, which, due to multiple biochemical reactions results in a variety of molecules such as coumarins $\left(C_{6}-C_{3}\right)$, flavonoids $\left(C_{6}-C_{3}-C_{6}\right)$, cinnamic acids $\left(C_{6}-C_{3}\right)$ or benzoic acids $\left(C_{6}-C_{1}\right)$ (Pereira et al., 2009). The phenolic compounds identified in this study are biosynthesized by the phenylpropanoids pathway which starts from amino acid phenylalanine to produce the cinnamic acids trans-cinnamic, 4-coumaric and ferulic acids. The cinnamic acids are the precursors of benzoic acids, flavonoids and coumarins. Interestingly, in vitro seedlings present contrasting phenolic content of cinnamic acids compared to wild plants and this results in changes in the levels of downstream phenylpropanoid pathway metabolites. Undoubtedly, factors as age, nutriments, and light exposure, among others may be influencing the metabolomic fluxes (Naik and Al-Khayri, 2016).

The great structural diversity observed in plant phenolic compounds may result in several biological activities that can be displayed by products containing these molecules. For example, scopoletin is a coumarin with anti-inflammatory activity associated with the inhibition of eicosanoid biosynthesis (Ding et al., 2008), 4-coumaric acid is a phenol with anti-inflammatory capacity suppressing the activity of cyclooxygenase 2 (Luceri et al., 2004), vanillic acid has the capacity to prevent liver diseases by reducing bilirubin (Atefipour et al., 2016) and ferulic acid, a major phenolic compound present in all tissue extracts of $R$. rossii, is an important compound in the prevention of oxidative stress and has a nephroprotective effect (Bami et al., 2017).

Finally, one of the most relevant phenolic compounds identified in $R$. rossii, which can be used either for medicinal or biotechnological purposes, are those also found in the orchid Vanilla planifolia Andrews, one of the primary sources for vanilla flavouring in food industry due to its high vanillin and vanillic acid content, among oth- ers (Divakaran et al., 2016). Although vanilla flavouring can now be produced by synthetic approaches, natural sources of these compounds are preferred by consumers around the world due to the flavour contribution of other compounds different from vanillin and vanillic acid. This has been one of the main reasons why research groups are interested in the development of culturing strategies for V. planifolia either in in or ex vitro conditions (Divakaran and Babu, 2009; Ramírez-Mosqueda and Iglesias-Andreu, 2017). A similar phenolic profile found in in vitro cultivated plants represents the capacity and opportunity that in vitro culture techniques offer to produce secondary metabolites of interest like wild plants do (Guerriero et al., 2018). Hence, the identification of novel sources of phenolic compounds with known applications from additional natural sources still is an opportunity area for scientists and very attractive for food, pharmaceutical and biotechnological industries.

\section{Conclusions}

This is the first report of phenolic compounds in wild plants and in vitro tissues of $R$. rossii, being the roots those that presented the highest concentration of phenolic compounds. In this study it is shown that through biotechnological method of plant tissues in vitro culture it is possible to support the rescue, care and study of endangered species, as well as to propose strategies to obtain bioactive compounds than can be exploited for several areas of industry without disturbing the environment.

\section{Author contributions}

AGS, NSMC, YCR conceived and designed the study. JAGA and JLMV contributed to the acquisition and interpretation of data by LC-MS. AGS wrote the manuscript with the help of NSMC, YCR, JLMV and JAGA. All authors contributed to the discussion, revision and approved the final version of the manuscript.

\section{Funding}

This research was supported by SAGARPA-SENASICA through a collaborative agreement with the Instituto de Ecología, A.C. (INECOL) (SENASICA-INECOL, 2016). 


\section{Acknowledgements}

The authors are grateful to Sergio Avendaño Reyes and Carlos Manuel Durán Espinosa from the Herbarium XAL of INECOL for taxonomic identification of the study species.

\section{Literature cited}

Atefipour, N., M. Dianat, M. Badavi and A. Sarkaki. 2016. Ameliorative effect of vanillic acid on serum bilirubin, chronotropic and dromotropic properties in the cholestasis induced model rats. Electron Physician 8(5): 2410-2415. DOI: https://doi. org/10.19082/2410

Baltazar-Bernal, O., J. Zavala Ruiz, F. Solís Zatonelli, J. Pérez Sato and O. Sánchez Eugenio. 2014. Sendero interpretativo de orquídeas y bromelias en Tepexilotla, Chocamán, Veracruz. Revista Mexicana de Ciencias Agrícolas 5(9): 1687-1699. DOI: https://doi.org/10.29312/remexca.v0i9.1057

Bami, E., O. B. Ozakpinar, Z. N. Ozdemir-Kumral, K. Köroglu, F. Ercan, Z. Cirakli, T. Sekerler, F. V. Izzettin, M. Sancar and B. Okuyan. 2017. Protective effect of ferulic acid on cisplatin induced nephrotoxicity in rats. Environmental Toxicology Pharmacology 54: 105-111. DOI: https://doi.org/10.1016/j. etap.2017.06.026

Bhattacharyya, P., S. Kumaria, R. Diengdoh and P. Tandon. 2014. Genetic stability and phytochemical analysis of the in vitro regenerated plants of Dendrobium nobile Lindl., an endangered medicinal orchid. Meta Gene 2: 489-504. DOI: https://doi.org/10.1016/j.mgene.2014.06.003

Bhatnagar, M., N. Sarkar, N. Gandharv, O. Apang, S. Singh and S. Ghosal. 2017. Evaluation of antimycobacterial, leishmanicidal and antibacterial activity of three medicinal orchids of Arunachal Pradesh, India. BMC Complementary and Alternative Medicine 17(379). DOI: https://doi.org/10.1186/ s12906-017-1884-z

Brand-Williams, W., M. E. Cuvelier and C. Berset. 1995. Use of a free radical method to evaluate antioxidant activity. LWTFood Science and Technology 28(1): 25-30. DOI: https://doi. org/10.1016/S0023-6438(95)80008-5

Cano Asseleih, L. M., R. A. Menchaca García and J. Y. S. Ruiz Cruz. 2015. Ethnobotany, pharmacology and chemistry of medicinal orchids from Veracruz. Journal of Agricultural Science and Technology 5: 745-754. DOI: https://doi. org/10.17265/2161-6256/2015.09.006
Castañeda-Zárate, M., J. Viccon-Esquivel, S. Ramos-Castro and R. Solano-Gómez. 2012. Registros nuevos de Orchidaceae para Veracruz, México. Revista Mexicana de Biodiversidad 83(1): 281-284. DOI: https://doi.org/10.22201/ ib.20078706e.2012.1.1226

Castillo-Pérez, L. J., D. Martínez-Soto, J. J. Maldonado-Miranda, A. J. Alonso-Castro and C. Carranza-Álvarez. 2019. The endemic orchids of Mexico: a review. Biologia 74(1): 1-13. DOI: https://doi.org/10.2478/s11756-018-0147-x

Chand, M. B., M. R. Paudel and B. Pant. 2016. The antioxidant activity of selected wild orchids of Nepal. Journal of Coastal Life Medicine 4(9): 731-736.

Chase, M. W., K. M. Cameron, J. V. Freudenstein, A. M. Pridgeon, G. Salazar, C. van den Berg and A. Schuiteman. 2015. An updated classification of Orchidaceae. Botanical Journal of the Linnean Society 177(2): 151-174. DOI: https://doi.org/10.1111/ boj.12234

Chen, Y., U. M. Goodale, X.-L. Fan and J.-Y. Gao. 2015. Asymbiotic seed germination and in vitro seedling development of $\mathrm{Pa}$ phiopedilum spicerianum: an orchid with an extremely small population in China. Global Ecology and Conservation 3: 367378. DOI: https://doi.org/10.1016/j.gecco.2015.01.002

Chugh, S., S. Guha and I. U. Rao. 2009. Micropropagation of orchids: A review on the potential of different explants. Scientia Horticulturae 122(4): 507-520. DOI: https://doi.org/10.1016/j. scienta.2009.07.016

Cruz-Higareda, J. B., B. S. Luna-Rosales and A. Barba-Álvarez. 2015. A novel seed baiting technique for the epiphytic orchid Rhynchostele cervantesii, a means to acquire mycorrhizal fungi from protocorms. Lankesteriana 15(1): 67-76. DOI: https:// doi.org/10.15517/lank.v15i1.18525

Di Ferdinando, M., C. Brunetti, G. Agati and M. Tattini. 2014. Multiple functions of polyphenols in plants inhabiting unfavorable Mediterranean areas. Environmental and Experimental Botany 103: 107-116. DOI: https://doi.org/10.1016/j.envexpbot.2013.09.012

Ding, Z., Y. Dai, H. Hao, R. Pan, X. Yao and Z. Wang. 2008. Anti-inflammatory effects of scopoletin and underlying mechanisms. Pharmaceutical Biology 46(12): 854-860. DOI: https:// doi.org/10.1080/13880200802367155

Divakaran, M. and K. N. Babu. 2009. Micropropagation and in vitro conservation of vanilla (Vanilla planifolia Andrews). 
In: Jain, S. M. and P. K. Saxena (eds.). Protocols for in vitro cultures and secondary metabolite analysis of aromatic and medicinal plants. Humana Press. Totowa NJ, USA. Pp. 129138. DOI: https://doi.org/10.1007/978-1-60327-287-2_11

Divakaran, M., K. N. Babu and K. V. Peter. 2016. Protocols for biotechnological interventions in improvement of vanilla ( $\mathrm{Va}$ nilla planifolia Andrews). In: Jain, S. (ed.). Protocols for in vitro cultures and secondary metabolite analysis of aromatic and medicinal plants. Humana Press. New York, USA. Pp. 47-63. DOI: https://doi.org/10.1007/978-1-4939-3332-7_4 Espinosa-Leal, C. A., J. F. Treviño-Neávez, R. A. Garza-Padrón, M. J. Verde-Star, C. Rivas-Morales and M. E. Morales-Rubio. 2015. Contenido de fenoles totales y actividad anti-radical de extractos metanólicos de la planta silvestre y cultivada in vitro de Leucophyllum frutescens. Revista Mexicana de Ciencias Farmacéuticas 46(3): 52-56.

Fay, M. F. 2018. Orchid conservation: how can we meet the challenges in the twenty-first century? Botanical Studies 59: 16. DOI: https://doi.org/10.1186/s40529-018-0232-z

Ganesan, K. and B. Xu. 2017. A critical review on polyphenols and health benefits of black soybeans. Nutrients 9(5): 455. DOI: https://doi.org/10.3390/nu9050455

Giri, L., P. Dhyani, S. Rawat, I. D. Bhatt, S. K. Nandi, R. S. Rawal and V. Pande. 2012. In vitro production of phenolic compounds and antioxidant activity in callus suspension cultures of Habenaria edgeworthii: A rare Himalayan medicinal orchid. Industrial Crops and Products 39: 1-6. DOI: https://doi. org/10.1016/j.indcrop.2012.01.024

Guerriero, G., R. Berni, J. A. Muñoz-Sánchez, F. Apone, E. M. Abdel-Salam, A. A. Qahtan, A. A. Alatar, C. Cantini, G. Cai, J-F. Hausman, K. S. Siddiqui, S. M. T. Hernández-Sotomayor and M. Faisal. 2018. Production of plant secondary metabolites: examples, tips and suggestions for biotechnologists. Genes 9(6): 309. DOI: https://doi.org/10.3390/genes9060309

Hinsley, A., H. J. de Boer, M. F. Fay, S. W. Gale, L. M. Gardiner, R. S. Gunasekara, P. Kumar, S. Masters, D. Metusala, D. L. Roberts, S. Veldman, S. Wong and J. Phelps. 2018. A review of the trade in orchids and its implications for conservation. Botanical Journal of the Linnean Society 186(4): 435-455. DOI: https://doi.org/10.1093/botlinnean/box083

Hussain, M. S., S. Fareed, S. Ansari, M. A. Rahman, I. Z. Ahmad and M. Saeed. 2012. Current approaches toward production of secondary plant metabolites. Journal of Pharma- cy and Bioallied Sciences 4(1): 10-20. DOI: https://doi. org/10.4103/0975-7406.92725

Ješvnik, T. and Z. Luthar. 2015. Successful disinfection protocol for orchid seeds and influence of gelling agent on germination and growth. Acta Agriculturae Slovenica 105: 95-102. DOI: https://doi.org/10.14720/aas.2015.105.1.10

Jiménez-Peña, N., L. I. Trejo-Téllez and P. Juárez-López. 2018. Concentración de macronutrimentos de tres especies silvestres de Rhynchostele en su hábitat natural. Revista Mexicana de Ciencias Agrícolas 9(5): 971-980. DOI: https://doi. org/10.29312/remexca.v9i5.266

Juárez-Trujillo, N., J. L. Monribot-Villanueva, M. Alvarado-Olivares, G. Luna-Solano, J. A. Guerrero-Analco and M. Jiménez-Fernández. 2018. Phenolic profile and antioxidant properties of pulp and seeds of Randia monantha Benth. Industrial Crops and Products 124: 53-58. DOI: https://doi.org/10.1016/j.indcrop.2018.07.052

Khamchatra, N., K. W. Dixon, S. Tantiwiwat and J. Piapukiew. 2016. Symbiotic seed germination of an endangered epiphytic slipper orchid, Paphiopedilum villosum (Lindl.) Stein. from Thailand. South African Journal of Botany 104: 76-81. DOI: https://doi.org/10.1016/j.sajb.2015.11.012

Lin, D., M. Xiao, J. Zhao, Z. Li, B. Xing, X. Li, M. Kong, L. Li, Q. Zhang, Y. Liu, H. Chen, W. Qin, H. Wu and S. Chen. 2016. An overview of plant phenolic compounds and their importance in human nutrition and management of type 2 diabetes. Molecules 21(10): 1374. DOI: https://doi.org/10.3390/molecules 21101374

Luceri, C., F. Guglielmi, M. Lodovici, L. Giannini, L. Messerini and P. Dolara. 2004. Plant phenolic 4-coumaric acid protects against intestinal inflammation in rats. Scandinavian Journal of Gastrienterology 39(11): 1128-1133.

Menchaca-García, R. and D. Moreno-Martínez. 2010. Rhynchostele rossii (Lindl) Soto Arenas \& Salazar. Especie en notable peligro. In: Gómez-Pompa, A., T. Krömer and R. Castro-Cortés (eds.). Atlas de la flora de Veracruz: un patrimonio natural en riesgo. EDIMPLAS. Xalapa, México. Pp. 481-482.

Minh, T. N., P. T. Tuyen, D. T. Khang, N. V. Quan, P. T. T. Ha, N. T. Quan, Y. Andriana, X. Fan, T. M. Van, T. D. Khanh and T. D. Xuan. 2017. Potential use of plant waste from the moth orchid (Phalaenopsis sogo yukidian V3) as an antioxidant source. Foods 6(10): 85. DOI: https://doi.org/10.3390/ foods 6100085 
Murashige, T. and F. Skoog. 1962. A revised medium for rapid growth and bioassays with tobacco tissue cultures. Physiologia Plantarum 15(3): 473-497. DOI: https://doi. org/10.1111/j.1399-3054.1962.tb08052.x

Murthy, H. N., E. Lee and K. Paek. 2014. Production of secondary metabolites from cell and organ cultures: strategies and approaches for biomass improvement and metabolite accumulation. Plan Cell Tissue and Organ Culture 118: 1-16. DOI: https://doi.org/10.1007/s11240-014-0467-7

Naik, P. M. and J. M. Al-Khayri. 2016. Impact of abiotic elicitors on in vitro production of plant secondary metabolites: A review. Journal of Advanced Research in Biotechnology 1(2): 7. DOI: https://doi.org/10.15226/2475-4714/1/2/00102

Pandey, K. B. and S. I. Rizvi. 2009. Plant polyphenols as dietary antioxidants in human health and disease. Oxidative Medicine and Cellular Longevity 2(5): 270-278. DOI: https://doi. org/10.4161/oxim.2.5.9498

Pant, B. 2013. Medicinal orchids and their uses: Tissue culture a potential alternative for conservation. African Journal of Plant Science 7(10): 448-467. DOI: https://doi.org/10.5897/ AJPS2013.1031

Paul, S., S. Kumaria and P. Tandon. 2012. An effective nutrient medium for asymbiotic seed germination and large-scale in vitro regeneration of Dendrobium hookerianum, a threatened orchid of northeast India. AoB Plants 2012(1): plr032. DOI: https://doi.org/10.1093/aobpla/plr032

Pereira, D. M., P. Valentão, J. A. Pereira and P. B. Andrade. 2009. Phenolics: From Chemistry to Biology. Molecules 14(6): 22202211. DOI: https://doi.org/10.3390/molecules14062202

Petruk, G., R. Del Giudice, M. M. Rigano and D. M. Monti. 2018. Antioxidants from plants protect against skin photoaging. Oxidative Medicine and cellular Longevity. 2018(2): 1-11, ID 1454936. DOI: https://doi.org/10.1155/2018/1454936

Ramakrishna, A. and G. A. Ravishankar. 2011. Influence of abiotic stress signals on secondary metabolites in plants. Plant Signaling and Behavior 6(11): 1720-1731. DOI: https://doi. org/10.4161/psb.6.11.17613

Ramírez-Mosqueda, M. A. and L. G. Iglesias-Andreu. 2017. Vanilla (Vanilla planifolia Jacks.) cell suspension cultures: establishment, characterization, and applications. 3 Biotech 7: 242. DOI: https://doi.org/10.1007/s13205-017-0871-x

Rasmussen, H. N., K. W. Dixon, J. Jersáková and T. Těšitelová. 2015. Germination and seedling establishment in orchids: a com- plex of requirements. Annals of Botany 116(3): 391-402. DOI: https://doi.org/10.1093/aob/mcv087

Rasouli, H., M. H. Farzaei and R. Khodarahmi. 2017. Polyphenols and their benefits: A review. International Journal of Food Properties 20(2): 1700-1741. DOI: https://doi.org/10.1080/ 10942912.2017.1354017

SEMARNAT. 2010. NORMA Oficial Mexicana NOM-059-SEMARNAT-2010. Protección ambiental-Especies nativas de México de flora y fauna silvestres-Categorías de riesgo y especificaciones para su inclusión, exclusión o cambio-Lista de especies en riesgo. Secretaría del Medio Ambiente y Recursos Naturales. Diario Oficial de la Federación. Cd. Mx., México. http://dof.gob.mx/nota_detalle.php?codigo=5173091 \&fecha=30/12/2010.

Singleton, V. L. and J. A. Rossi. 1965. Colorimetry of total phenolics with phosphomolybdic-phosphotungstic acid reagent. American Journal of Enology and Viticulture 16(3): 144-158.

Tokuhara, K. and M. Mii. 2001. Induction of embryogenic callus and cell suspension culture from shoot tips excised from flower stalk buds of Phalaenopsis (Orchidaceae). In vitro Cellular and Developmental Biology - Plant 37: 457-461. DOI: https://doi.org/10.1007/s11627-001-0080-4

Utami, E. S. W., S. Hariyanto and Y. S. W. Manuhara. 2017. In vitro propagation of the endangered medicinal orchid, Dendrobium lasianthera J.J. Sm through mature seed culture. Asian Pacific Journal of Tropical Biomedicine 7(5): 406410. DOI: https://doi.org/10.1016/j.apjtb.2017.01.011

Wang, T.-Y., Q. Li and K.-S. Bi. 2018. Bioactive flavonoids in medicinal plants: structure, activity and biological fate. Asian Journal of Pharmaceutical Sciences 13(1): 12-23. DOI: https:// doi.org/10.1016/j.ajps.2017.08.004

Zhang, S., Y. Yang, J. Li, J. Qin, W. Zhang, W. Huang and H. Hu. 2018. Physiological diversity of orchids. Plant Diversity 40(4): 196208. DOI: https://doi.org/10.1016/j.pld.2018.06.003

Zhishen, J., T. Mengcheng and W. Jianming. 1999. The determination of flavonoids contents in mulberry and their scavenging effects on superoxide radicals. Food Chemistry 64(4): 555559. DOI: https://doi.org/10.1016/s0308-8146(98)00102-2

Zotz, G. and U. Winkler. 2013. Aerial roots of epiphytic orchids: the velamen radicum and its role in water and nutrient uptake. Oecologia 171: 733-741. DOI: https://doi.org/10.1007/ s00442-012-2575-6 